\title{
Polymorphism of $B M P 2$ Gene Associated with Growth Traits in Guizhou Semi-Fine Wool Sheep
}

\author{
${ }^{1} \mathrm{Li}$ Juan $\mathrm{Li},{ }^{3}$ Yong Jun Li, ${ }^{3} \mathrm{Wen}$ Ting Li, ${ }^{4}$ Xin Wang and ${ }^{1,2}$ Xiao Yun Shen \\ ${ }^{1}$ Pratacultural Ecological Institute, Academy for Bijie Experiment Region, \\ Bijie University, Bijie, 551700 Guizhou, P.R. China \\ ${ }^{2}$ College of Animal Science and Technology, Yangzhou University, 225009 Yangzhou, P.R. China \\ ${ }^{3}$ Chongqing University of Science and Technology, 401331 Chongqing, P.R. China \\ ${ }^{4}$ College of Animal Science and Technology, South China Agricultural University, \\ 510642 Guangzhou, P.R. China
}

\begin{abstract}
Bone Morphogenetic Protein 2 (BMP2) plays a crucial role in bone growth. The objective of this study was to investigate variations in sheep $B M P 2$ gene and their associations with growth traits in 320 Guizhou Semi-Fine Wool sheep. Five fragments of $B M P-2$ gene were investigated only exon2 region of $B M P-2$ gene showed polymorphism after PCR-SSCP and DNA sequencing methods. There was one G>A (g. $273 \mathrm{G}>\mathrm{A}$ ) mutation located in nucleotide position of GenBank Accession No. EU854586 which constructed three genotypes (LL, LW and WW). The frequencies of allele L and genotype LL were dominant in Guizhou SemiFine Wool sheep. The PIC (Polymorphism Information Content) values of the Guizhou Semi-Fine Wool sheep were 0.3261 belong to median polymorphism. Associations between growth traits and BMP2 gene polymorphism were investigated and significant statistical association results were found in body height, body length and chest circumference $(\mathrm{p}<0.05)$. These results strongly suggested that the $B M P 2$ gene is a candidate gene that influences growth traits in Guizhou Semi-Fine Wool sheep. Further investigations are required for detecting the polymorphism of this gene in a broad variety of sheep breeds and populations.
\end{abstract}

Key words: $B M P-2$ gene, Guizhou Semi-Fine Wool sheep, growth traits, body height, China

\section{INTRODUCTION}

Bone Morphogenetic Proteins (BMPs) were firstly identified as a protein which can inducing new bone formation in muscle tissue, they are members of the TGF- $\beta$ (Transforming Growth Factor- $\beta$, TGF- $\beta$ ) superfamily, later they were purified to a small molecule protein named as BMPs (Urist, 1965). The amino acid of BMPs contains seven conserved cysteine (Wozney, 1992), most of them have two identical subunits, the subunits linked by disulfide. According to the homology BMPs family divided into four subgroups: the BMP-2/BMP-4 subgroups, the BMP-5/BMP-6/BMP-7/BMP-8 subgroups, the BMP-3/ BMP-12/ BMP13/ BMP1 4 subgroups and the BMP9 subgroups (Liu et al., 2005; Ducy and Karsenty, 2000). With the success of BMP5, BMP6 and BMP7 cDNA cloning, the BMPS gene studying into deep research stage (Sato et al., 1999). So far, $>40$ BMPs have been identified in the superfamily (Wang et al., 2009).

The human $B M P-2$ gene has been obtained by Wozney et al. (1988), it maps to chromosome at 20p-12 and has 3 coding exons which encodes 396 amino acids, the cDNA length were $1188 \mathrm{bp}$ (Dubois et al., 1995). Most result showed that the polymorphisms of $B M P-2$ gene were associated with osteoporosis (Styrkarsdottir et al., 2003) bone mineral density, fractures and bone growth (Solheim, 1998; Choi et al., 2006; McGuigan et al., 2007). Okubo implanted BMP-2 collagen in different parts of rats vivo, contains muscle, intramuscular, subcutaneous and fat, the results showed that in all parts found ectopic bone (Kanzler et al., 2000). Whether in vivo or in vitro experiments have revealed the BMP-2 has the ability to promote osteoblast differentiation and induced bone formation (Ichikawa et al., 2006).

Recently research trends revealed that the BMPs play an important role in skeletal development (Orazizadeh et al., 2009; Salari and Abdollahi, 2011). $\mathrm{BMP}-2$ is considered to be the most important BMP to the skeleton. In poultry, it is reported the polymorphism of $B M P-2$ gene was associated with the metatarsus length of chicken (Leng et al., 2007). In goat, the $3^{\prime}$ flanking region of $B M P-2$ gene showed polymorphism, it was associated

Corresponding Author: Xiao Yun Shen, Academy for Bijie Experiment Region, Pratacultural Ecological Institute, Bijie University, HuanDong Road, Bijie, 551700 Guizhou, P.R. China 
in body trunk index (Fang et al., 2010). Till now, there was no report about polymorphisms of $B M P-2$ gene in sheep. Guizhou Semi-Fine Wool sheep is a local sheep breed in China which have strong adaptation and fitness in Southwest alpine pasture of China. But the Guizhou SemiFine Wool sheep have relatively low production and slow growth. With the development of economics in Southwest of China, the demand for mutton and wool were increased, the Guizhou Semi-Fine Wool sheep can not meet the need. Genetic improvement of native breeds in wool and grow traits is desirable because of the adaptation and fitness of these breeds in their production environment. However, breed improvement through traditional genetics and breeding methods is difficult because of the demographics of the sheep herds and extensive production systems in Southwest of China (Subramanian et al., 2005).

So, it is very important to identify the suitable candidate markers correlated with wool and grow traits in this breed. As a consequence, variation in BMP2 gene was investigated in 320 Guizhou Semi-Fine Wool sheep using PCR Single Strand Conformation Polymorphism (PCR-SSCP) and DNA sequencing analysis.

\section{MATERIALS AND METHODS}

Animal source: Venous jugular blood samples were collected from 320 Guizhou Semi-Fine Wool sheep random which were reared in two different State-owned sheep farms of Guizhou Native Sheep-Breeding Center (Weining Sheep Breeding Farm and Cold Water Ditch Sheep Breeding Farm). Data of body weight, body length, body height and chest circumference measured on all 320 Guizhou Semi-Fine Wool sheep for statistical analysis.

DNA sample preparation: Genomic DNA samples were extracted from blood samples according to standard phenol-chloroform protocol (Mullenbach et al., 1989).

PCR amplification: Based on the high homology among bovine, goat and sheep $B M P-2$ gene, five pairs of primers (Table 1) P1-P5 were designed from the published gene sequence (GenBank Accession No. BC134682, EU854586 and AY714781). The P1 amplify the exon2, the P2-P4 amplify exon3 and the P5 amplify partial 3 ' Untranslated Regions (UTR) of the sheep $B M P-2$ gene.

A $25 \mu \mathrm{L}$ PCR solution containing $50 \mathrm{ng}$ DNA template, $10 \mathrm{pmol}$ of each primer, $0.20 \mathrm{mM}$ dNTP, $2.5 \mathrm{mM}$ $\mathrm{MgCl}_{2}$ and $0.5 \mathrm{U}$ Taq DNA polymerase (Dingguo, Beijing, China) was used. The PCR was performed using the following program: $95^{\circ} \mathrm{C}$ for $5 \mathrm{~min}$ followed by 34 cycles of $94^{\circ} \mathrm{C}$ for $30 \mathrm{sec} ; 40 \mathrm{sec}$ for annealing and $45 \mathrm{sec}$ extension at $72^{\circ} \mathrm{C}$ followed by $10 \mathrm{~min}$ at $72^{\circ} \mathrm{C}$ for the final extension. PCR products were electrophoresed on $1.5 \%$ agarose gels using $1 \times$ TBE buffer ( $89 \mathrm{mM}$ Tris, $89 \mathrm{mM}$ boric acid, $2 \mathrm{mM}$ $\mathrm{Na}_{2}$ EDTA) containing $200 \mathrm{ng} \mathrm{mL}^{-1}$ Golden View (Solarbio, Beijing, China).

Single Strand Conformation Polymorphism (SSCP) and DNA sequencing: SSCP Method was used to scan mutations within the amplified regions. Aliquots of $5 \mu \mathrm{L}$ PCR products were mixed with $5 \mu \mathrm{L}$ denaturing solution (95\% formamide deionized, $25 \mathrm{mM} \mathrm{EDTA}, 0.025 \%$ xylenecyanole and $0.025 \%$ bromophenol blue) heated for $10 \mathrm{~min}$ at $98^{\circ} \mathrm{C}$ and chilled in ice immediately. Denatured DNA was subjected to $10 \%$ PAGE (Polyacrylamide Gel Electrophoresis) in $1 \times \mathrm{TBE}$ buffer and constant voltage $(130 \mathrm{~V})$ for $14 \mathrm{~h}$ at a constant temperature of $4^{\circ} \mathrm{C}$ and then gels were stained with $0.1 \%$ silver nitrate. Genotypes were assigned according to the PCR products of different electrophoresis patterns (Fig. 1) for each individual. The different electrophoresis patterns were sequenced in both directions and analyze the sequences with BioXM Software (Version 2.6).

Statistical analysis: Statistical analysis was performed on the basis of records of body weight, body height, body length, chest circumference in 320 Guizhou Semi-Fine Wool sheep. Genotypic frequencies, allelic frequencies and Hardy-Weinberg equilibriums were directly calculated. Population genetic indexes (Gene heterozygosity, gene homozygosity and effective allele numbers) were calculated by Nei methods (Nei and Roychoudhury, 1974).

Table 1: Primers used for Polymerase Chain Reaction (PCR) amplification

\begin{tabular}{llccc}
\hline Locus Sequences & $\begin{array}{l}\text { Size } \\
(\mathrm{bp})\end{array}$ & $\begin{array}{c}\text { Temp. } \\
\left({ }^{\circ} \mathrm{C}\right)\end{array}$ & $\begin{array}{c}\text { BasedGenBank } \\
\text { Accession No. }\end{array}$ \\
\hline P1 & F: TTCTAGCGTTGCTGCTTCCC & 315 & 57 & EU854586 \\
& $\begin{array}{l}\text { R: GGTGAAAGCTGCGCACTGT } \\
\text { P2 }\end{array}$ & & & \\
& F: ACTTGTACCGCCAGCACTC & 239 & 60 & BC134682 \\
P3 & $\begin{array}{l}\text { R: AGCTTCGGGCATATGTTC } \\
\text { F: CCCACTGAGGAGTTATC }\end{array}$ & 406 & 55 & BC134682 \\
& $\begin{array}{l}\text { R: GTGTCCTTCCCATCGTG } \\
\text { P4 }\end{array}$ & & & \\
& F: CCACGATGGGAAAGGACAC & 389 & 58 & BC134682 \\
P5 & $\begin{array}{l}\text { RCTAACGACACCCACAACC } \\
\text { F: GTCGTTAGCACAGCAAAATA }\end{array}$ & 386 & 59 & AY714781 \\
& R: GTACAAACCCAATACTTCCT & & & \\
\hline
\end{tabular}

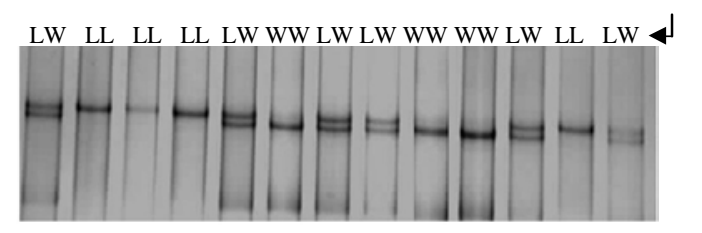

Fig. 1: The electrophoresis patterns of PCR-SSCP for Guizhou Semi-Fine Wool sheep BMP-2 gene P1 locus 
The Polymorphism Information Content (PIC) was calculated according to Botstein et al. (1980). The following statistical model was fitted to compare differences in growth trains among different genotypes with random residual used as error (SPSS, Inc., Shanghai, PRC, Version 15.0):

\begin{tabular}{|c|c|c|}
\hline \multicolumn{3}{|c|}{ Where: } \\
\hline Y & $=$ & The observation of the trait \\
\hline$\mu$ & $=$ & The least square mean \\
\hline Sex & $=$ & The effect of sex \\
\hline Age & $=$ & The effect of age \\
\hline Farm & $=$ & The effect of farm \\
\hline $\mathrm{E}$ & $=$ & The random error \\
\hline
\end{tabular}

\section{RESULTS}

Polymorphism of five loci: Researchers preliminarily carried out five pairs of primers to detect the genetic variation of Guizhou semi-fine wool sheep BMP-2 gene by PCR-SSCP and DNA pool sequencing methods. Only the P1 locus that was exon2 regions showed polymorphism. Three unique PCR-SSCP banding patterns were detected after electrophoresis (Fig. 1), they were designated as genotype LL, LW and WW.

BMP-2 gene sequencing: In P1 locus, DNA from six randomly chosen Guizhou Semi-Fine Wool sheep for different SSCP patterns were cloned and sequenced in both directions, some of their sequences were deposited in the GenBank database (Accession No. JN015066 and JN015067). DNA sequencing analysis revealed one $\mathrm{G}>\mathrm{A}$ mutation located in (g. $273 \mathrm{G}>\mathrm{A}$ ) nucleotide position of GenBank Accession No. EU854586, it was existed in the $B M P-2$ gene exon2 (Fig. 2), after analysis this mutant is synonymous mutation which didn't casuals the amino acids change.

Analysis of polymorphism of the $B M P-2$ gene in the Guizhou semi-fine wool sheep: Genotypic and allelic frequencies was calculated (Table 2). The frequencies of allele L and genotype LL were 0.520 and 0.350 . Population genetic indexes (namely, Homozygosity (Ho), Heterozygosity $(\mathrm{He})$, effective allele Numbers $(\mathrm{Ne})$ and Polymorphism Information Content (PIC)) were calculated according to Nei and Li (1979). Guizhou semi-fine wool sheep populations belonged to a median polymorphism level (Table 3).

Association of polymorphisms of the P1 locus with growth traits in the Guizhou semi-fine wool sheep: The relationships between genotypes and four growth traits

Table 2: Genotypic distribution and allelic frequencies of Guizhou Semi-Fine Wool sheep $B M P-2$ gene

ObserDed genotypes and

their frequencies Allele frequencies

\begin{tabular}{|c|c|c|c|c|c|c|}
\hline \multirow[b]{2}{*}{ Parameters } & \multicolumn{3}{|c|}{ their frequencies } & \multirow[b]{2}{*}{ Total } & \multicolumn{2}{|c|}{ Allele frequencies } \\
\hline & LL & LW & WW & & $\mathrm{L}$ & W \\
\hline Number & 112.000 & 109.000 & 99.000 & 320 & 0.520 & 0.480 \\
\hline Frequencies & 0.350 & 0.341 & 0.309 & - & - & - \\
\hline
\end{tabular}

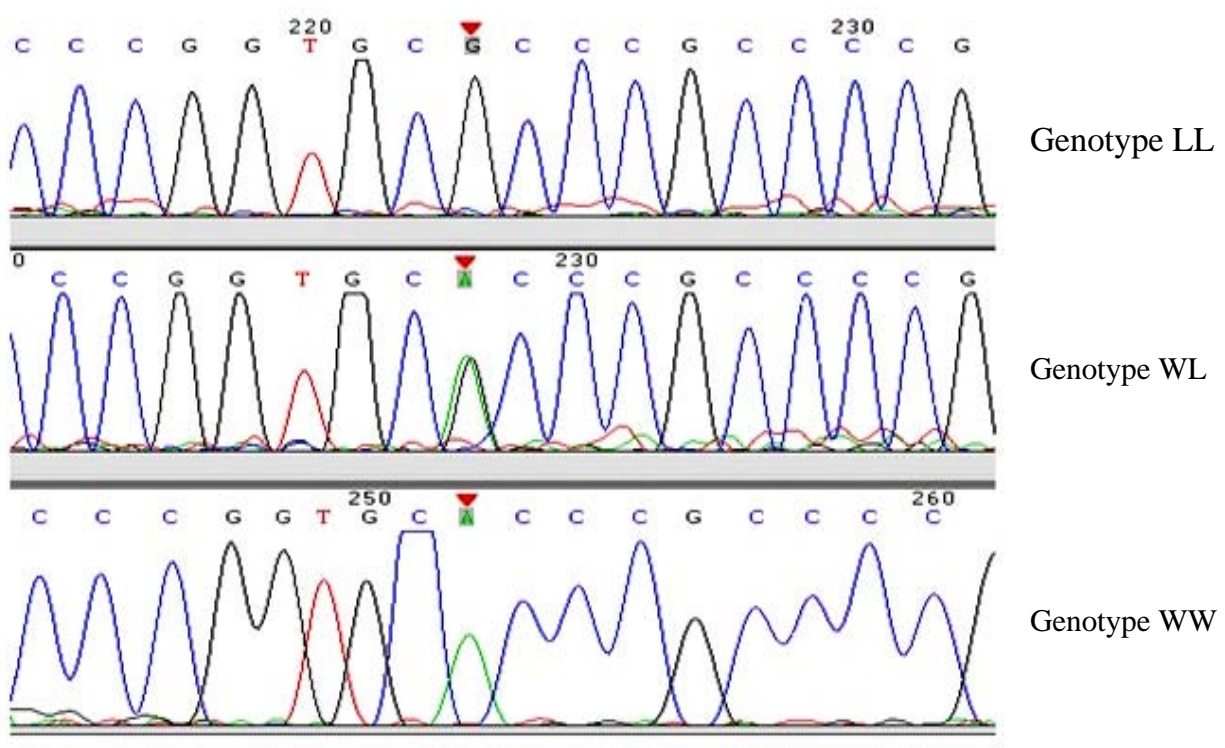

Fig. 2: Sequencing maps from different genotypes of Guizhou Semi-Fine Wool sheep BMP-2 gene P1 locus 
Table 3: Genetic diversity estimates for Guizhou Semi-Fine Wool sheep $B M P-2$ gene

\begin{tabular}{lccccc}
\hline Gene Homozygosity (Ho) & Gene Heterozygosity (He) & $\begin{array}{c}\text { Effective allele } \\
\text { No. (Ne) }\end{array}$ & $\begin{array}{c}\text { Polymorphism } \\
\text { Information Content (PIC) }\end{array}$ & $\chi^{2}$ (HW*) & p-value (HW*) \\
\hline 0.5008 & 0.4992 & 1.9967 & 0.3746 & 32.2832 & $\mathrm{p}<0.05$ \\
\hline
\end{tabular}

HW $=$ Hardy-Weinberg equilibrium

Table 4: Means for BMP-2 genotypes for production traits of Guizhou Semi-Fine Wool sheep

\begin{tabular}{lllll}
\hline & Mean \pm SE & & & \\
Traits & LL $(\mathrm{n}=112)$ & LW $(\mathrm{n}=109)$ & WW $(\mathrm{n}=99)$ & $\mathrm{p}$-value \\
\hline Body weight $(\mathrm{kg})$ & $45.917 \pm 1.646$ & $42.998 \pm 2.364$ & $46.667 \pm 2.346$ & $\mathrm{p}>0.05$ \\
Body height $(\mathrm{cm})$ & $63.817 \pm 0.922^{\mathrm{a}}$ & $64.009 \pm 0.902^{\mathrm{b}}$ & $63.665 \pm 0.862^{\mathrm{ab}}$ & $\mathrm{p}<0.05$ \\
Body length $(\mathrm{cm})$ & $62.069 \pm 0.943^{\mathrm{a}}$ & $63.108 \pm 0.923$ & $63.193 \pm 0.881$ & $\mathrm{p}<0.05$ \\
Chest circumference $(\mathrm{cm})$ & $80.179 \pm 1.252^{\mathrm{a}}$ & $81.915 \pm 1.226$ & $81.966 \pm 1.170$ & $\mathrm{p}<0.05$ \\
\hline Means on the same line with different superscripts differ $(\mathrm{p}<0.05)$ & & &
\end{tabular}

(body weight, body height, body length and chest circumference) were analyzed (Table 4). There was a significant different in body height, body length and chest circumference between genotypes $(\mathrm{p}<0.05)$. It was indicated that individuals with genotype WW were significantly higher than those of individuals with genotype LL in body height, body length and chest circumference.

\section{DISCUSSION}

The BMP2 gene is widely used in studies of association with osteoporosis (Choi et al., 2006; McGuigan et al., 2007; Medici et al., 2006; Schrauwen et al., 2008), bone mineral density (Styrkarsdottir et al., 2003; Ichikawa et al., 2006), regulate plate chondrogenesis (De Luca et al., 2001) and repair of bone defects (Yue et al., 2005) in human and rat and in recent years, the polymorphisms of $B M P 2$ gene and livestock growth traits were reported in goat and chicken. Fang studied BMP2 gene polymorphisms in three goats breeds and find one mutation in 3 ' flanking region which have a significant effect in body trunk index $(\mathrm{p}<0.05)$ (Fang et al., 2010). Leng reported a 12 bp insertion/deletion at BMP2 gene intron2 in chicken which associated with skeletal traits (Leng et al., 2007). But there was no report about $B M P 2$ gene polymorphisms of sheep.

The research attempted to detect and characterize polymorphisms within the coding region and $3^{\prime}$ untranslated regions of $B M P 2$ gene in 320 individuals of Guizhou Semi-Fine Wool sheep. After sequencing, the alignment between nucleotide sequences of goat in GenBank (Accession No. EU854586) and the sequencing results of PCR products with same patterns revealed that their homology reached up to $99 \%$. It has been reported that this gene was highly evolutionary conserved in mammals (Tabas et al., 1991), this result was a good authentication for it. A novel SNP $\mathrm{G}>\mathrm{A}$ ) was detected at the exon2 region. The results showed that the genotype LL was a predominant genotype and $\mathrm{L}$ was a predominant allele. Different banding patterns were sequenced in both directions and were published in the GenBank database (GenBank accession JN015066, JN015067).

Population genetic indexes (namely, Homozygosity (Ho), Heterozygosity ( $\mathrm{He})$, effective allele Numbers $(\mathrm{Ne})$ and Polymorphism Information Content (PIC)) were calculated. If $\mathrm{PIC}, \mathrm{Ne}$ and $\mathrm{He}$ are larger, the number of genetic variation of this locus will be more in this breed and it will make this gene an obvious candidate to investigate whether variants impart differences in growth traits. According to the classification of PIC (low polymorphism if $\mathrm{PIC}$ value $<0.25$, median polymorphism if $0.25<\mathrm{PIC}$ value $<0.5$ and high polymorphism if $\mathrm{PIC}$ value $>0.5$ ) (Botstein et al., 1980), Guizhou Semi-Fine Wool sheep was at median polymorphism.

\section{CONCLUSION}

The present study reveals that the polymorphism of the $B M P 2$ gene exon2 is significantly associated with growth traits in body height, body length and chest circumference of Guizhou Semi-Fine Wool sheep. The sheep with genotype WW however, do tend to be better than those with genotype LL in growth traits.

The mutational population had inferior genotype in this study so the result suggests that the $B M P 2$ gene could play an important role in the process of growth in the Guizhou Semi-Fine Wool sheep. To date, few polymorphisms about the sheep $B M P-2$ gene have been reported, researchers firstly determine the novel genetic variations of the sheep $B M P-2$ gene by PCR-SSCP and DNA sequencing methods. However, these results should be considered as preliminary, further investigations will be necessary for detecting the polymorphism of this gene in a broad variety of sheep breeds and populations. 


\section{ACKNOWLEDGEMENTS}

This study was supported by the Earmarked Fund for China Modern Agro-industry Technology Research System (CARS-40-30), Governor Special Funds of Guizhou province (NO.GSS 2009 (129) CHA), Scientific and Technological Support Projects of Guizhou province (NO.GSCNY [2010] 3041).

\section{REFERENCES}

Botstein, D., R.L. White, M. Skolnick and R.W. Davis, 1980. Construction of a genetic linkage map in man using restriction fragment length polymorphisms. Am. J. Hum. Genet., 32: 314-331.

Choi, J.Y., C.S. Shin, Y.C. Hong and D. Kang, 2006. Singlenucleotide polymorphisms and haplotypes of bone morphogenetic protein genes and peripheral bone mineral density in young Korean men and women. Calcified Tissue Int., 78: 203-211.

De Luca, F., K.M. Barnes, J.A. Uyeda, S. de Levi and V. Abad et al., 2001. Regulation of growth plate chondrogenesis by bone morphogenetic protein-2. Endocrinology, 142: 430-436.

Dubois, C.M., M.H. Laprise, F. Blanchette, L.E. Gentry and R. Leduc, 1995. Processing of transforming growth factor beta 1 precursor by human furin convertase. J. Biol. Chem., 270: 10618-10624.

Ducy, P. and G. Karsenty, 2000. The family of bone morphogenetic proteins. Kidney Int., 57: 2207-2214.

Fang, X., H. Xu, C. Zhang, J. Zhang, X. Lan, C. Gu and C. Hong, 2010. Polymorphisms in BMP-2 gene and their associations with growth traits in goats. Genes Genomics, 32: 29-35.

Ichikawa, S., M.L. Johnson, D.L. Koller, D. Lai and X. Xuei et al., 2006. Polymorphisms in the Bone Morphogenetic Protein 2 (BMP2) gene do not affect bone mineral density in white men or women. Osteoporosis Int., 17: 587-592.

Kanzler, B., R.K. Foreman, P.A. Labosky and M. Mallo, 2000. BMP signaling is essential for development of skeletongenic and neurogenic cranial neural crest. Development, 127: 1095-1104.

Leng, L., Q.G. Wang and Y.X. Wang, 2007. Association of polymorphisms of BMP-2 gene with bone growth traits in Chinese chicken. Memoir of the 14th Meeting on Animal Genetics and Breeding in China.

Liu, J.B., F. Wang and W.H. Rong, 2005. Advance of bone morphogenetic proteins. Livest. Feed Sci., 4: $35-37$.
McGuigan, F.E., E. Larzenius, M. Callreus, P. Gerdhem, H. Luthman and K. Akesson, 2007. Variation in the BMP-2 gene: Bone mineral density and ultrasound in young adult and elderly women. Calcified Tissue Int., 81: $254-262$.

Medici, M., J.B. van Meurs, F. Rivadeneira, H. Zhao and P.P. Arp et al., 2006. BMP-2 gene polymorphisms and osteoporosis: The Rotterdam study. J. Bone Mineral Res., 21: 845-854.

Mullenbach, R., P.J. Lagoda and C. Welter, 1989. An efficient salt-chloroform extraction of DNA from blood and tissue. Trends Genet., 5: 391-391.

Nei, M. and A.K. Roychoudhury, 1974. Sampling variance of heterozygosity and genetic distance. Genetics, 76: 379-390.

Nei, M. and W.H. Li, 1979. Mathematical model for studying genetic variation in terms of restriction endonucleases. Proc. Natl. Acad. Sci. USA., 76: 5269-5273.

Orazizadeh, M., M. Hashemitabar, M. Fakoor and M.T. Moghadam, 2009. Effect of bone morphogenetic protein-2 on normal and osteoarthritic human articular chondrocytes. Pak. J. Biol. Sci., 12: 1194-1199.

Salari, P. and M. Abdollahi, 2011. A comprehensive review of the shared roles of inflammatory cytokines in osteoporosis and cardiovascular diseases as two common old people problem: Actions toward development of new drugs. Int. J. Pharmacol., 7: 552-567.

Sato, M., T. Ochi, T. Nakase, S. Hirota, Y. Kitamura, S. Nomura and N. Yasui, 1999. Mechanical tensionstress induces expression of Bone Morphogenetic Protein (BMP)-2 and BMP-4, but not BMP-6, BMP-7 and GDF-5 mRNA, during distraction osteogenesis. J. Bone Mineral Res., 14: 1084-1095.

Schrauwen, I., M. Thys, K. Vanderstraeten, E. Fransen and N. Dieltjens et al., 2008. Association of bone morphogenetic proteins with otosclerosis. J. Bone Mineral Res., 23: 507-516.

Solheim, E., 1998. Current concepts: Growth factors in bone. Int. Orthopedics, 22: 410-416.

Styrkarsdottir, U., J.B. Cazier, A. Kong, O. Rolfsson and H. Larsen et al., 2003. Linkage of osteoporosis to chromosome 20p12 and association to BMP2. PLoS Biol., 1: e69-e69.

Subramanian, S., T. Karthik and N.N. Vijayaraaghavan, 2005. Single nucleotide polymorphism for animal fibre identification. J. Biotechnol., 116: 153-158.

Tabas, J.A., M. Zasloff, J.J. Wasmuth, B.S. Emanuel and M.R. Altherr et al., 1991. Bone morphogenetic protein: Chromosomal localization of human genes for BMP1, BMP2A and BMP3. Genomics, 9: 283-289. 
Urist, M.R., 1965. Bone: Formation by autoinduction. Science, 150: 893-899.

Wang, P.Q., Y. Yan, M.X. Chu, R. Di and L. Fang, 2009. Cloning and sequence analysis on exons of bone morphogenetic protein 2 gene in goats. Chin. Anim. Husbandry Vet. Med., 36: 59-64.

Wozney, J.M., 1992. The bone morphogenetic protein family and osteogenesis. Mol. Reprod. Dev., 32: $160-167$.
Wozney, J.M., V. Rosen, A.J. Celeste, L.M. Mitsock and M.J. Whitters et al., 1988. Novel regulators of bone formation: Molecular clones and activities. Science, 242: 1528-1534.

Yue, B., B. Lu, K.R. Dai, X.L. Zhang, C.F. Yu, J.R. Lou and T.T. Tang, 2005. BMP2 gene therapy on the repair of bone defects of aged rats. Calcified Tissue Int., 77: $395-403$. 